ISSN: 2036-5438

\title{
Some considerations on the relationship between economic and social cohesion and implementation of the cohesion policy
}

by

Małgorzata Dziembała*

Perspectives on Federalism, Vol. 8, issue 1, 2016 


\section{Abstract}

The processes of deepening economic integration and regional development contribute to the intensification of inter-regional disparities. The EU's efforts to achieve cohesion are intended to contribute to lifting the level of socio-economic development, improving the quality of life of residents, and also solving emerging problems, including social ones, so that the benefits of growth spread evenly across the EU. This inevitably has the implication, in the name of solidarity principle, of the need to provide support to countries and regions at a disadvantage to achieve cohesion within the EU. The Union promotes economic, social and territorial cohesion among Member States (MS) through grants of financial assistance and in the many benefits achieved from the implementation of EU policies. One of these policies is the cohesion policy, the aim of which is to achieve a social, economic and territorial cohesion within the Union.

This paper aims to identify current perceptions of cohesion in the EU. Here we will argue that there is no conflictual relationship between economic and social cohesion; that both dimensions are self-reinforcing, and economic cohesion presupposes social cohesion. The paper also discusses the socio-economic cohesion of Poland and its regions against the background of the new EU MS. It will also assess the contribution of EU cohesion policy in the socio-economic development of Polish regions.

\section{Key-words}

Cohesion policy, economic and social cohesion, structural funds 


\section{Introduction}

The EU's primary concern is fostering solidarity among the MS, e.g. through the implementation of common policies (Mik 2009: 49-50). It has a practical application in the activities undertaken to achieve cohesion in the economic, social and territorial dimensions of the Union. The processes of deepening economic integration and regional development contribute to the intensification of inter-regional disparities. ${ }^{\mathrm{I}} \mathrm{A}$ view to ensure cohesion in its three dimensions is born in mind here; as stated in Art. 3 (3) TEU 'The Union [...] promotes economic, social and territorial cohesion and solidarity among Member States. ${ }^{\text {II }}$

Cohesion policy provides financial aid to the poorer EU MS and their regions, and the operation of this policy is subordinate to the principle of solidarity. Financial resources are largely directed to the least developed regions. In 2007-2013, the financial resources allocated to this category of regions accounted for approximately $81.5 \%$ of the cohesion policy budget. ${ }^{\mathrm{III}}$ The intensity of this aid in the poorest regions is expected to reach $€ 180$ per capita in 2014-2020, which means a significant reduction compared to the period 20002004 when it accounted for $€ 259$. Cohesion policy has to fulfil many tasks, although its budget is relatively small, representing $0.36 \%$ of GNI (gross national income) in 2012. ${ }^{\text {IV }}$ However, it is the main source of funding for projects aimed at counteracting existing disparities and improving the competitiveness of regions. Since the inception of this policy, its objectives and principles have been reframed. Still, without its operation, it would be impossible to create social and economic model of the EU, of which the foundations are basic values such as solidarity, and which distinguishes the EU from other players of the world economy.

Economic solidarity in the context of cohesion policy should not be achieved only through the institutionalised transfers of funds made from relatively wealthy countries to less-favoured countries or regions, but would look much more widely, through the prism of mutual benefits gained by both donors and beneficiaries of this aid and the whole the EU. The implementation of this policy in regions is now necessary to overcome the negative consequences of the economic crisis, as will be reflected in the decreased disparity, 
or nett improvement of living standards, and the improved level of development in the group of countries and their regions included in the mechanism of this solidarity.

This paper aims to identify the current perception of cohesion in the EU and discusses the socio-economic cohesion of Poland and its regions against the background of the new EU MS. It will also assess the contribution of EU cohesion policy to the socio-economic development of Polish regions. The author makes an attempt to verify the hypothesis that there is no conflictual relationship between economic and social cohesion policies, and that moreover both dimensions are self-reinforcing and the economic cohesion presupposes social cohesion.

\section{Achieving economic, social and territorial cohesion in the context of implementing the EU socio-economic model}

The developing process of European integration takes place in the economic, as well as the social sphere, and these are closely interwoven (Schiek 2013: 49-51). The actions implemented in the framework of EU economic policy, shaped by complex conditions, contribute to the implementation of the European economic and social model. In the Europe 2020 Strategy, which is the exit program from the crisis of the Union, a vision of the development of this group is outlined, whilst also offering a model of the economy whose achievement will be sought by taking appropriate measures. The proposed model for economic growth in this strategy should not only be associated with an increase in GDP. Indeed, the priorities of the EU will be smart, sustainable and inclusive growth. Support for the economy will be promoted in such a way as to achieve a high level of employment, improved efficiency in the EU, and improved competitiveness, without harming the social market economy model implemented in the EU (European Commission 2010: 2-3, 5, 11-12; European Commission 2014: 3).

The development of the economic and social model of the EU was influenced by the financial and economic crisis and affected the solutions adopted by the Union's policymakers in the sense that it was necessary to use appropriate instruments, and to introduce such management methods in the EU as to reduce its negative consequences. This model can be equated with a set of complex mechanisms and instruments to enable the functioning of the EU, contributing to the achievement of its complex objectives, including 
economic and social cohesion at different levels: European, within individual MS, as well as on the regional level, at the same time conditioning further development of this group (Dziembała 2013: 372).

Achieving economic and social cohesion took on special significance in the EU due to the asymmetric impact of the financial and economic crisis in different regions within the EU. It is also a result of policies being implemented in the EU - restrictive macroeconomic, fiscal policies, and macroeconomic effects of the crisis. One should take into account the fact that in the period of economic downturn the resilience of the MS to this kind of phenomenon varies, as well as the outcome of the implementation of different policies. At the same time, the presence of weaker states and their regions in the EMU makes the impact of negative economic phenomena on regional development in each country different, embodied in the form of so-called 'domestic effects' (when considering the economic results achieved in all regions of the EU). The effects of the crisis have an asymmetric spatial dimension because of the diversity of economic structures of the regions and their allocation of territorial capital. There are also different effects on the demand side, inter alia, visible in the decline in investment, mainly affecting regions dependent on the industry with a high proportion of SMEs. Moreover, in the subsequent phases of the crisis, different types of regions were affected by its consequences in different ways, not only the less developed regions, outermost and farming regions, but also export-oriented regions or industrial regions (Camagni, Capello 2015: 28-32).

According to the last report from the Commission on economic and social cohesion, a deceleration of the process of reducing disparities between regions in 2008-2011 occurred, not only in terms of GDP per capita, but also with regard to other indicators such as levels of employment, and unemployment. Deepening regional disparities took place after 2008. The consequences of the crisis affected regions with different levels of economic development (European Commission 2014a: 1-7), thereby impacting on economic and social cohesion in the EU.

As a consequence, much attention was needed in the direction of policy actions which would contribute to the achievement of cohesion, both in the economic and social dimension (Rodrígues-Pose, Tselios 2015: 31). Indeed, the social consequences inherent in a period of economic downturn cannot be forgotten; here, issues of strengthening social cohesion in the EU have been undertaken in the Europe 2020 strategy. In fact, sustainable 
development is promoted here, it is noted that while taking action not only economic criteria, economic growth, should be accounted for, but also social categories should be included (European Commission 2010). Therefore, a discussion was conducted regarding growth and its sustainability in the context of achieving cohesion in both dimensions, and at the same time implications that are associated with its attainment.

The existence of regional disparities impacts on national economies. Unused labour resources, and production potential, lowers national prosperity. Thus, the relevant policies aimed at these resources affect the economic results achieved by a national economy, improve the efficiency and quality of life, and hence social well-being in the regions. However, it may turn out that while some regions benefit from the adopted strategy of development of a given national economy, in others, where capital and resources are not utilized, there may be a need to implement policies aimed at achieving social equality in the regions lagging behind (Martin 2008: 3-4).

Cohesion is a multifaceted concept, and it can be argued that it is a 'state of community of interests' that is to be achieved. It also means targeting entities, and individuals, with the objectives established in the EU system (Tondl 1995: 8-11). The categories of economic and social cohesion are difficult to be treated separately, not least in the formulation of policies and directions of the proposed support. These two dimensions of cohesion contribute to each other and are characterised by interconnectedness and feedback.

Economic cohesion is associated with actions aimed at not only reducing disparities in development, but also at improving the dynamics of development of regions and increasing their competitiveness. ${ }^{\text {VI }}$ As pointed out by M.G. Woźniak, economic cohesion is an instrument for achieving social cohesion as the former 'is [...] to serve business entities and local communities to achieve well-being and enable them to limit the differences in the level and quality of life by eliminating sources of exclusion from the processes of modernisation'(Woźniak 2012: 7). Efforts to improve the situation on the labour market will also affect the living standards of the population, and thus the existing degree of exclusion of the population (Ministry of Infrastructure and Development, 2014: 86). Therefore, the issues of social cohesion cannot be neglected, as they have been so far, and are becoming pivotal to the achievement of economic cohesion, and thus development, which should be more inclusive. Social cohesion has been associated with such positive 
dimensions as a sense of belonging, active participation, and perhaps even trust, as well as being defined in the light of existing inequalities, such as exclusion (OECD 2011: 53).

According to the OECD, social cohesion can be seen through three components: social inclusion, social capital (combining trust and various forms of social engagement), and social mobility (OECD 2011: 17, 53-54), seen as 'measuring the degree to which people may or believe that they will change their position in society' (OECD 2011: 54). It is emphasized that the existence of social cohesion contributes to economic growth, to the reduction of poverty, to the effectiveness of public policies, and moreover it affects the sustainability of economic growth (OECD 2011: 54, 58).

The assessment of economic cohesion perceived in the light of the ongoing development processes, and thus convergence, is the subject of numerous analyses (Barro, Sala-i-Martin 1991: 107-182). Analysis of the importance of social cohesion for the growth of regional economies, or the EU, has also been conducted. The importance of social cohesion on a regional basis for maintaining sustainable growth is emphasized by Ch. Benner, and M. Pastor, who studied growth within 184 metropolitan areas in the United States in the years 1990-2011. They proved that the durability of growth spells, through the creation of increased employment and higher real wages, are related to factors such as low levels of dependency on processing industries, and a higher proportion of people who hold secondary education level. However, as they argue, the length of growth spells is also influenced by factors related to social cohesion and, therefore, political fragmentation fragmentation of local government, a high level of racial segregation, and a high level of income inequality which may contribute to shorter growth spells in the economy. The sustainability of this growth is impacted by the levels of inequality; the region which is more socially integrated will be able to sustain this growth (Benner, Pastor 2014: 1-18).

In contrast, A. Rodrígues-Pose and V. Tselios examine social cohesion in the field of social welfare considered in the light of Sen's social welfare index. They emphasize that the process of convergence at the regional level in the EU takes place not only in the economic field, but also social one. A lack of existing process of economic convergence is not necessarily linked to the same phenomenon in the social sphere. Indeed, the social convergence process is advancing, and regions with a lower initial level/degree of welfare 'grow' much faster. Additionally, clusters of regions with similar levels of welfare can be identified. A gap in welfare is less visible due to the intensification of social policy activities. 
Many factors influence the progressive process of convergence in welfare (growth rate) and the authors identify them with structural and institutional factors, among others, such as: level of education attained, access to work (participation in the labour market), participation of women in the labour market, which is the most important factor, urbanisation, infrastructure, etc. (Rodrígues-Pose, Tselios 2015: 30-60). In this context, promoting the EU's economic model, attention should be paid to actions for social cohesion in order to ensure its long-term and sustainable development.

Nevertheless, the category of cohesion has been enriched by its territorial dimension. It has been indicated that 'this cohesion serves a means of transforming diversity into an asset that contributes to sustainable development of the entire EU' (European Commission 2010a: 3). According to the Green Paper, territorial cohesion will address three areas, concentration, connectivity and cooperation.

The first of these, concentration, relates to measures relating to excessive concentration of growth areas, as well as access to the benefits connected with the functioning of an agglomeration, based on cooperation, interactions and connections with the areas surrounding cities. Despite the benefits arising from the concentration of economic activity, it will be necessary to overcome the negative externalities of agglomeration, suppressing differences in distance when it comes to the intermediate regions, i.e. the rural areas. The second, connectivity, relates to the development of links between the territories by overcoming the distance and is related to, among others, the connectivity of intermodal transport, access to services, access to the sources of energy, energy network connections, Internet access, links between enterprises and research centres. The third dimension is in cooperation, promoting bridging differences through implementation of multi-level cooperation structures involving public and private entities to solve the problems of each area. Territorial cohesion will be manifested in directing actions to regions with specific geographical features which include: mountainous regions, island regions and sparsely populated regions, and other regions with specific conditions (European Commission 2010a: 6-9; Green Paper on Territorial Cohesion, the way ahead, 2008: 4-6). The framework for the development of the territorial dimension of Europe and identified priorities for territorial development in the EU is presented in Agenda 2020 (Agenda Terytorialna Unii Europejskiej). The territorial dimension must also be reflected in the implementation of the Europe 2020 Strategy and the implementation of EU policies. Therefore, those key aspects, 
which need to be considered while preparing appropriate planning documents related to cohesion policy, include: accessibility, services of general economic interest, territorial potential, networks of cities, and functional regions (Ministry of Regional Development 2011: 7-9).

\section{Economic and social cohesion in the new EU Member States}

A wide variety of political, cultural and social factors have resulted in the boundary defining the economic division of Europe into its richer and poorer part now running between the western and eastern part of the continent, where in the middle of the twentieth century it existed between the north and the south. In fact, in 1950-1989, the countries of Central and Eastern Europe (CEE) were subjected to economic degradation, and at the end of this period they were in the group of least developed European countries (Orłowski 2010a: 19-22). ${ }^{\text {VII }}$ With EU membership their economic development has accelerated, not only as a result of their membership in the EU structures, but also the ongoing process of transformation in these countries.

However, the CEE countries, despite convergence processes, remain in the group of EU countries with lowest levels of socio-economic development. In 2011, Cyprus achieved the best results in terms of GDP per capita in this group of countries, which amounted to 94\% of the average values for the EU-28 (according to PPS), and the worst - Bulgaria, whose GDP per capita was 47\% of the EU average. In 2011, the richest region in the EU13 was Bratislava, with a GDP per capita of $186 \%$ of the EU average, followed by Prague (171\% of the EU-28 average) and only 9 regions had a GDP per capita higher than $75 \%$ of the EU average. The poorest was the Romanian region of Nord-Est $(29 \%$ of the EU average GDP). In 2003, the ratio between the richest and the poorest regions of the CEE countries, which have become members of the EU, represented 7.3: 1, in 2011 it was 6.4: 1. ${ }^{\text {VIII }}$ Most of the regions belonging to this group of countries are beneficiaries of aid from EU funds earmarked for the least favoured regions. Following this, how is economic and social cohesion shaped in this group of countries and what changes are taking place in their regions in terms of membership in the EU in the scope of economic and social cohesion?

In order to obtain an answer to the questions, a study was conducted using a set of variables characterising economic and social cohesion. The following variables were used: 
unemployment rate $(\%)$, economic activity rate $(\%)$, average life expectancy, fertility rate, and households' disposable income (HDI), expressed in euros per inhabitant (Dziembała 2013). The study covered the following three-year periods: 2003-2005, 2006-2008 and 2009-2011, for which average values of the data were calculated. ${ }^{\text {IX }}$ The analysis of economic and social cohesion was carried out for the CEE countries, as well as for their regions. Initially 58 regions in the EU-13 were selected for analysis, but Cyprus, two Croatian regions and Malta were not included in the calculation due to lack of data. Croatia, Cyprus and Malta were excluded from the countries' analysis due to the lack of data on HDI.

The cluster analysis carried out according to J.H. Ward's method made it possible to define groups of countries similar to each other following the adopted set of variables. Three clusters were identified; however, due to interpretation issues, a division at a lower level was adopted by selecting four clusters for economic and social cohesion, covering the period of 2003-2005. Slovenia was included in the first cluster (Class I) characterised by the best economic potential due to very favourable indicators among the other classes: above average HDI per capita, the highest rate of life expectancy, a relatively low unemployment rate, a relatively high economic activity rate of the population. Still, attention needs to be paid to the demographic potential due to a below average fertility rate. In contrast, Class IV included Romania and Bulgaria, namely countries that were characterised by the lowest economic potential of the analysed group of countries, taking into account the HDI per capita, low economic activity rates, low life expectancy, where these variables are below average for this group of countries. In contrast, cluster III covered Hungary and the Czech Republic due to the very high, above average HDI per capita, and low unemployment rate. The remaining group, which includes class II, included countries with an average HDI per capita and moderate growth prospects, in which attention should be paid to the need for human resource management.

The results of clustering for the period of 2006-2008 demonstrated the sustainability of the current situation of countries in each group (i.e. according to four classes). Class III included the Czech Republic only, and Hungary was among 'inbetweeners', there were no other changes in the countries belonging to various classes. These results were confirmed by the analysis for the years 2009-2011, only in Class III Slovakia joined the Czech Republic. Slovakia came out of the group of average regions, since it improved, except for 
the labour activity rate, all factors included in the analysis, in particular HDI per capita. The indices analysed for this country were above average and they included: the economic activity rate, life expectancy and HDI per capita. The high unemployment rate still remains a problem, which indicates the need for human resources management. The countries' classification results according to J.H. Ward's method for the years 2009-2011 are shown in Fig. 1.

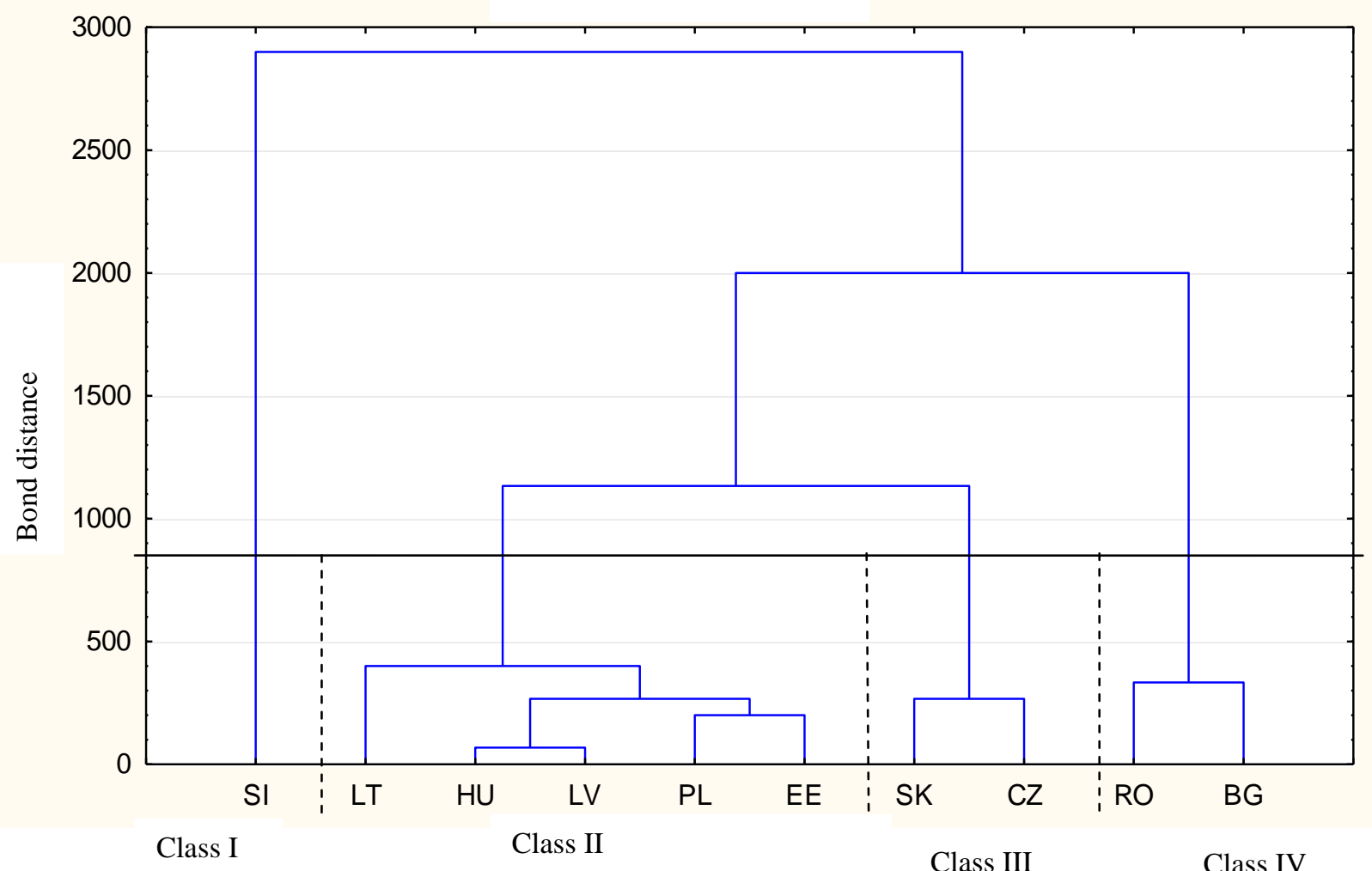

Fig. 1. Classification of the EU-10 $\mathrm{x}$ according to the economic and social cohesion in 20092011

Source: own elaboration.

The results confirm that changes in the EU-10 countries are slowly taking place, as countries' identification with particular groups is relatively stable. The analysis of the average values of the data for subsequent periods shows that there was a gradual improvement, with the exception of the unemployment rate. The gradual advancement in the level of welfare is not only proved by improved HDI per capita, but also the average 
life expectancy, which is affected by active interventions implemented within the framework of national economic policies. On the other hand, the analysis of the average rate of unemployment for this group of countries shows that there was a decline in this respect in the period of 2006-2008, and then the rate increased, exceeding the average values for a group of countries at the baseline. Thus, this indicates that despite the still improving economic capacities of these countries, the problem of social cohesion is an urgent matter to be solved, especially under the conditions of economic turbulence.

How is, then, economic and social cohesion shaped on a regional basis in the group of countries analysed? The regions were divided into 3 clusters using the method of k-means. In order to identify the optimal number of clusters, the agglomeration method of J.H. Ward was applied.

Based on average values calculated for economic and social cohesion for the period of 2003-2005, clustering of the regions was carried out. The best cluster following the adopted set of variables was cluster 2 covering 14 regions (representing 25.9\% of the analysed regions): all Czech regions with the exception of Moravskoslezsko region, 2 out of 7 Hungarian regions including the capital, Bucharest region, 2 regions of Slovenia and 2 Slovak regions, including Bratislava. Analysis of average values of variables for each cluster showed that cluster 2 has the best values for the adopted coefficients. Only the fertility rate for this group of countries was the lowest. Therefore, these regions are of high economic potential, but attention should be paid to the improvement of the demographic potential.

Cluster 1 included 21 regions representing 38.9\% of all analysed regions and these were all Bulgarian regions, Estonia, Lithuania, Latvia, 6 Hungarian regions and 7 out of 8 Romanian regions. This cluster is characterised by the lowest HDI per capita, and an average life expectancy, the lowest coefficient of labour economic activity and the highest fertility rate. This group of regions is characterised by the lowest economic potential, whereas it has good demographic potential and satisfactory use of human resources.

In contrast, cluster 3 covered all Polish regions, one Czech region and 2 Slovak regions characterised by great demographic potential, but untapped human capital due to the highest average unemployment rate.

In the next period of the analysis, covering the average data for the period of 20062008, in the group of the best regions there were already 17 regions, and the 'worst' - 16 regions. 
Based on average data for the period of 2009-2011, clustering of regions was carried out. Cluster 3 consisted of 12 regions, and included countries characterised by the best economic potential, the average demographic potential and a relatively good use of human resources. This cluster comprised all Czech regions, Mazowieckie Voivodship (a Polish region), all Slovenian regions and Bratislava. This means that some regions definitely improved their socio-economic situation while considering their belonging to the various clusters, in particular, these were the capitals compared to the first period covered by the analysis.

In contrast, cluster 1 included countries characterised by the lowest HDI and average life expectancy, and, therefore, the lowest economic potential, but significant demographic potential and untapped human capital. This cluster was made up of 11 regions, i.e. 5 out of 6 Bulgarian regions, Lithuania, Latvia, Estonia, 1 Hungarian region and 2 Slovak regions.

Compared to the analysis of the first period, the number of regions classified in the cluster with the worst economic performance decreased. In addition, the unemployment rate was the highest among all analysed clusters, which, as it can be assumed, was affected by the economic crisis and its consequences in the social sphere. These regions which improved or worsened their position were in cluster 2. Cluster 2 consisted of 31 regions, representing $57 \%$ of the regions covered by the analysis. It was one Bulgarian region - the capital Sofia, 6 Hungarian regions, all Polish regions with the exception of the capital and all Romanian regions and one Slovak region. Particular attention should be paid to Romanian regions, which clearly passed from the group of regions with the worst position to the regions with average results. The analysis of the average data for the period of 20092011 compared to the period of 2003-2005 indicates a decrease in the unemployment rate, increase in the labour activity ratio and life expectancy, and improvement of the HDI in Romanian regions. They were in the same group as the Hungarian regions, due to the decline in their unemployment rate, but there was an increase in HDI and in labour activity ratio.

The analysis showed that while countries allocation to each cluster is relatively stable, the regional situation is different as there is a reduction in the number of regions with the best or worst performance when comparing the results of the analysis for the period 20092011 with those for the period 2003-2005. The repercussions of the crisis had an impact on 
social cohesion, and activities that would counteract them should be given special attention.

Gradually, CEE countries and regions are improving their level of socio-economic development. While formulating goals and taking action within the framework of economic policy these two should not exclusively be seen in the context of short-term objectives, but also the long-term ones, of which social cohesion ought to be a determinant.

In a broader view, the adoption of convergence processes can be understood to be a prerequisite for the cohesion of this group of countries and the EU, not only in the economic and social aspect, but also in political one (Tondl 1995: 9).

\section{Benefits versus contributions of the cohesion policy}

In 2014-2020, the volume of financial resources for cohesion policy will be $€ 351.8 \mathrm{bn}$ (at current prices). ${ }^{\mathrm{XI}}$ Determining this element of the EU budget, and adopting solutions, was accompanied by numerous debates; some questioned the legitimacy of policy and questioned the meaning of its continued functioning.

However, solidarity should not be seen in the light of the costs of immediate compensation, but in the mutual benefits accruing to the members of the Union (Vignon 2011). The benefits of implementing a cohesion policy also apply to those countries which make the greatest contribution to the EU budget, and postulate its reduction. This assistance is becoming an important development impulse for them. As for A. Prusek writes, 'a membership fee to the EU budget is in fact a proportional contribution to the benefits gained by the country from the common market and, therefore, a specific turnover tax on economic benefits derived from the EU single market' (Prusek 2009: 99). These benefits are significant when considered from the perspective of both the EU as a whole and individual MS. Stronger EU countries have access to the markets of the weaker countries, and the recognised economic benefits are much higher than those achieved by the 'catching up' countries, for whom financial transfers from cohesion policy are provided. These transfers also help offset the costs of opening the countries and regions vulnerable to increased competition. Comparative advantages are generated in all EU countries (Prusek 2009: 98-102). 
This is confirmed by the results of research on the consequences of the implementation of cohesion policy in the Visegrad countries, the so-called V-4 (Poland, the Czech Republic, Slovakia, and Hungary). The benefits recognised by the EU-15 countries for the implementation of EU projects are macroeconomic, where employment growth takes place through increasing exports from countries in the EU-15 to the new MS enjoying economic development. Moreover, the EU-15 countries largely export medium and high technology products. Further integration of the economies occurs, where demand for products and services related to the implementation of EU projects comes largely from countries with which the beneficiaries of the aid have strong economic ties. There are also direct benefits, as companies implementing EU projects in the new MS develop additional production, they are reaping the benefits of capital. There are positive external effects reflected in the areas of $R \& D$ and innovation, as development of cooperation in science and research takes place, followed by improving conditions for research and development centres, human capital development, fuelling with their resources the EU-15 countries. The absorption capacity of companies from the new MS in the field of new technologies is improving, which contributes to the growth of technology exports from the EU-15 countries. There is also an increase in ecological safety, reducing pollution, and a development of infrastructure and transport links. In this way, cohesion policy funding costs incurred by the countries of 'old' EU are significantly reduced (Institute for Structural Research 2011).

Despite the undoubtedly positive effects of the implementation of cohesion policy, it is, however, necessary to take measures to increase positive public awareness of the EU's policies. EU politicians see the benefits gained from the implementation of cohesion policy, in particular in the EU-15 countries, as a means to gain greater support for joint integration actions, and for cohesion through the implementation of this policy. This is especially pertinent, given that the level of confidence in the EU among the EU population is still relatively low and amounted to $37 \%$ in 2014 (spring), a significant decrease compared to 2007 (autumn), when it accounted for 57\%, in a period of prosperity (European Commission 2014b: 8).

What is, then, the perception of cohesion policy among EU citizens? According to the results of Eurobarometer 2013, about a third of respondents indicated that they knew about the projects co-financed from EU funds, which contributed to the development of 
the area in which they live. At the same time, in countries where the majority of regions were convergence objective regions, knowledge of the projects co-financed with these funds is much greater. While $64 \%$ of respondents in the EU-13 countries (whose regions were in the majority covered by the convergence objective) indicated some knowledge of EU projects, in the EU-15 countries the awareness was only $26 \%$. In Poland, about $80 \%$ of the respondents indicated knowledge about projects co-financed with the EU, while in Great Britain only $10 \%$ of respondents, in Germany $15 \%$, France $28 \%$ and Portugal $51 \%$. Among the respondents with knowledge of EU funds, $77 \%$ of them pointed to the positive impact of the funds on the development of regions (cities), and the result is more favourable for the EU-13 (89\%) than for the EU-15 (69\%). In Poland, this percentage was $93 \%$ in 2013. It should be noted that the perception of current priorities for this assistance has changed. As many as $52 \%$ of Europeans said that measures of this policy should be directed to all regions (in $2010-49 \%$ ) and not only the poorest regions (Citizen's awareness and perceptions of EU regional policy: 4, 6-7, 10, 12, 29-30).

In post-crisis conditions one direction for the revival of solidarity and a restoration of support for the idea of the EU is to promote convergence, but a process of economic slowdown has also affected the countries of Central Europe. It partly resulted from the slowdown in reforms taking place in these countries and from the need to pursue a model of development based on innovation. Thus, the support of citizens for the European project will be gained. This is also in the interest of richer countries (Swieboda 2014: 44).

Moreover, as emphasised by R. Camagni, R. Capello, as a result of the crisis, additional divisions may be caused and the emergence of a two-speed Europe - less developing regions of the southern countries and regions of the northern countries may occur. The convergence process will slow down and it will not be sufficient to enable Eastern European countries to reach the level of GDP per capita of the countries in Western Europe by 2030. Thus, the effects of the crisis will be permanent and it will be difficult to overcome them (Camagni, Capello 2015: 30-31).

Varied activities to strengthen and intensify the process of convergence have been proposed, both at the EU level and in the MS, but the selection of actions that are most appropriate is an open issue (Swieboda 2014: 44-45). Undoubtedly, such actions have to be implemented by the cohesion policy. However, the assessment of the effects of the cohesion policy, its contribution to the process of economic growth, and hence 
convergence in the EU, is ambiguous. Some authors emphasise that the effectiveness of the policy depends on the fulfilment of certain conditions for positive processes to turn out to be reality (Baun, Marek 2014: 178-208).

\section{Implementation of cohesion policy in Poland and its effects}

With accession to the EU, Poland was included in the European cohesion policy. The role of this policy should be the creation of development impulses that will foster positive changes in areas that are at various stages of development. In particular, this concerns the first phase, during which an economy based on traditional factors of development, without innovative structures, develops by the expansion of production capacity and the improvement of the quality of the workforce. The second phase is associated with the qualitative restructuring of the economy, but with a low share of knowledge-based economy, and it is only the third phase that is associated with the development of an economy based on knowledge and innovation (Prusek 2009: 101-103). What, therefore, was the role of cohesion policy in the transformation of the Polish socio-economic area and in stimulating the development after more than 10 years of membership in the EU and what role can it play in the $2014-2020$ period?

Under the conditions of EU membership, Polish GDP growth was high in the period of 2003-2011, as GDP grew by 43.1\% (constant prices), with average annual growth rate of about $4.6 \%$, while for the EU-27 it amounted to $1.3 \%$ per year. On the other hand, if the analysis also included 2012, the average growth rate for Poland dropped to $4.3 \%$ per annum. These positive changes were a reflection of the faster growth of Polish economy in relation to the EU as a whole and in the process of 'catching up' (Misiag, Misiag, Tomalak 2013: 13). But it should not be forgotten that processes of transformation worked in parallel with the process of European integration, giving rise to a complex interrelationship in their progress.

In 2004-2006, Structural Funds that were provided for Poland amounted to $€ 8.3 \mathrm{bn}$, $€ 0.35 \mathrm{bn}$ from INTERREG and EQUAL Community Initiatives, €4.2bn from the Cohesion Fund (according to current prices). The Structural Funds were channelled through five operational programs (horizontal), one technical assistance program and the Integrated Operational Programme for Regional Development (Ministry of Regional 
Development 2007: 13-14). In the years 2007-2013 the allocation of funds from the EU budget for Poland amounted to $€ 67.3 \mathrm{bn}$, from this amount from the Convergence objective was allocated $€ 66.5 \mathrm{bn}$. If, however, the funds of the Common Agricultural Policy and Common Fisheries Policy were added, and contributions from other programmes supporting competitiveness, then the total amount of EU funds for Poland would amount to $€ 85.4 \mathrm{bn}$ (Ministry of Regional Development 2007: 115-116). The distribution of structural funds and the Cohesion Fund broken down into specific operational programmes for the period 2007-2013 is presented in Table 1. ${ }^{\text {III }}$

Table 1. Distribution of EU funds from the cohesion policy allocated to Poland for 20072013 under the operational programmes

\begin{tabular}{|l|c|c|l|}
\hline Operational programme & $\begin{array}{l}\text { Share of the programme } \\
\text { in total fund allocation } \\
\text { (in bn euros) }\end{array}$ & Percentage share & \multicolumn{1}{|c|}{ Source of funding } \\
\hline Infrastructure and Environment & 27.9 & 41.9 & ERDF, Cohesion Fund \\
\hline $\begin{array}{l}\text { Regional Operational Programmes } \\
\text { (16 Regional Operational } \\
\text { Programmes) }\end{array}$ & 16.6 & 24.9 & ERDF \\
\hline Human Capital & 9.7 & 14.6 & ESF \\
\hline Innovative Economy & 8.3 & 12.4 & ERDF \\
\hline Development of Eastern Poland & 2.3 & 3.4 & $\begin{array}{l}\text { ERDF (including } \\
\text { additional 992m euros } \\
\text { granted by the } \\
\text { European Council) }\end{array}$ \\
\hline Technical Assistance & & & ERDF \\
\hline
\end{tabular}

Source: Ministry of Regional Development 2007: 116.

The size of payments made to Poland under the Cohesion Policy (including the ISPA Fund) was $€ 13.1 \mathrm{bn}$ euros for payments made in the period of 2004-2006 and €45.6bn for 2007-2013. Poland is also the biggest net beneficiary among EU MS; in the years 20042012 the balance of EU transfers for Poland amounted to €53.6bn. By contrast, in terms of payments made per inhabitant Poland took 7th place among EU countries, exceeding the EU average. Poland utilizes the EU funds effectively, as the repayment did not exceed 0.2\% (Ministry of Infrastructure and Development, 2014: 13-15). However, the importance of these funds should be seen through their participation (including national co-financing) in public investment in Poland, which in 2010-2012 was above 50\% (c.f. Slovakia with 90\%) (European Commission 2014a: XVI). Therefore, this means that a significant part of the development investments in Poland could not be implemented without these funds. At the same time, such a significant share of EU funds indicates that cohesion policy impacts on the creation of domestic regional policy priorities, not always coinciding with the priorities of the EU, which also must be taken into account. 
Thus, what are the effects of this policy? It is emphasized that transfers of EU funds contributed to the relatively high economic growth recorded by Poland in the years 20042013, as well as cushioning the effects of the economic crisis in 2009-2010. And so in 2012, the GDP growth in Poland amounted to $1.9 \%$, with the impact of the funds estimated at 0.9 percentage points. European funds also had an impact on the process of raising the level of socio-economic development of the country (Ministry of Infrastructure and Development, 2014: 21-22). It should be emphasized that the gap between Polish regions and other European regions is closing, since 9 Polish voivodeships (regions) belonged to the 20 regions with the fastest rate of convergence in the EU in the period of 2004-2010. However, following expansion interregional disparities are developing, as the convergence process is carried out unevenly spatially (Ministry of Infrastructure and Development 2014: 7). It should also be noted that the improvement in the GDP per capita in the less favoured Eastern Polish regions, in relation to the EU average, is the result of GDP growth in both Poland and its regions, and of lower growth of GDP in the EU countries (Misiag, Misiag, Tomalak 2013: 85). What should be pointed out is the fact that the years 2004-2011 were followed by a more rapid development of these regions with a high initial level of GDP, and, even with lower dynamics in some regions these too were higher than the average for the EU. At the same time, however, the spread in terms of GDP did not decrease, but on the contrary, the gap between GDP per capita and the average national level in the Eastern Polish voivodeships is widening (Misiag, Misiag, Tomalak 2013: 15). In the years 2006-2011 Polish GDP grew by 43.7\% and in the Eastern Polish regions by 42.5\%, and this gap is expected to widen (Misiag, Misiag, Tomalak 2013: 44).

However, the impact of EU funds depends mainly on their total value, rather than their value per inhabitant. If we consider the value of EU funds provided per inhabitant (from all sources), they were, first of all, directed to the less developed regions in the period of 2004-2011. Nevertheless, these funds did not sufficiently contribute to boosting the economic development of the weakest regions, as their growth rate did not exceed that recorded by the more developed regions. If the size of these funds was analysed per inhabitant, they did not considerably affect the growth rate of regions, especially Eastern Polish regions, because there was no acceleration in the economic growth, as had been assumed. Regions where there are large cities are developing faster. However, further analysis of the size of these funds spent in the NUTS 3 territorial units reveals that they 
were largely concentrated in cities, which may be partly due to both their better absorption capacity or the activities of the authorities to invest these funds in these centres (Gorzelak 2014: 18-20; Misiag, Misiag, Tomalak 2013: 45-49). While there is no link between the amount of funds per capita and economic dynamics, there is a relationship between their absolute size and economic dynamics (Gorzelak 2014: 18-22; Misiag, Misiag, Tomalak 2013). In the period of 2004-2013, the largest EU funding was spent in relatively few voivodeships (Ministry of Infrastructure and Development, 2014: 15).

On the other hand, the analysis of the funding structure in 2004-2013 in individual voivodeships shows that European funding was mainly allocated to the improvement of territorial accessibility, with lesser amounts given to the development of human resources, research and development, entrepreneurship and environmental protection. The expenditure in the field of transport in the regions generally amounted from $25 \%$ to $45 \%$ of the funds, the development of human resources was allocated from $15 \%$ to $20 \%$ of the funds (in the general structure of expenditure), and funds allocated to research and technological development (the share of this category of expenditure in individual voivodeships accounted for $10 \%$ to $20 \%$ ). As much as $36 \%$ of the value of all contracts is related to transportation (Ministry of Infrastructure and Development 2014: 7-8, 19-20). As it is indicated, the EU funds had the primary impact on improving living conditions, and, therefore, the effect of strong investment demand supported by European funds was highlighted (Gorzelak 2014; Misiag, Misiag, Tomalak 2013).

From this analysis it can be argued that there was excessive emphasis on removing growth barriers through the expansion of basic social and technical infrastructure, to the detriment of other connected conditions: lack of personnel, research facilities, and business services. Also, the investments at the local and central level were mainly related to those aimed at improving living conditions, and to a lesser extent to the achievement of supply effects. At the same time, the ability to run pro-development projects was limited. In the less developed regions, the specific characteristics of the region and their potential were insufficiently taken into account when planning the utilization of the aid (Misiag, Misiag, Tomalak 2013: 85-86).

What, therefore, will be the shape of cohesion policy in Poland in the period of 20142020? The size of the allocation granted to Poland during this period will amount to $€ 82.5 \mathrm{bn}$, of which $€ 76.9 \mathrm{bn}$ will be allocated to the implementation of operational 
programs, of which those implemented in the regions will receive around $40 \%$. ${ }^{\mathrm{XII}}$ Still, European structural and investment funds will be an important source of investment financing in order to ensure its sustainability, as approximately one third of development costs will be borne by the EU (Programowanie perspektywy finansowej 2014-2020, 2014: 9). An important direction of support will be infrastructure, as an increase in funds for innovation and business support is expected. ${ }^{\mathrm{XIV}}$

Table 2. Distribution of EU funds within the framework of programmes (in bn euros) for the period of 2014-2020

\begin{tabular}{|l|r|r|}
\hline Name of programme & Amount of funds & Financial sourcing \\
\hline $\begin{array}{l}\text { Infrastructure and Environment } \\
\text { Programme }\end{array}$ & 27.41 & ERDF, CF \\
\hline Intelligent Development Programme & 8.61 & ERDF \\
\hline Digital Poland Programme Education Development & 2.17 & ERDF \\
\hline $\begin{array}{l}\text { Knowledge ESF } \\
\text { Programme }\end{array}$ & 4.69 & ERDF \\
\hline Eastern Poland Programme Assistance Operational & 2 & CF \\
\hline $\begin{array}{l}\text { Technical } \\
\text { Programme }\end{array}$ & 0.700 & ERDF, ESF \\
\hline Regional Operational Programmes & 31.28 & . \\
\hline
\end{tabular}

Source: $\quad$ http://www.mir.gov.pl/fundusze/fundusze_europejskie_2014_2020/strony/start.aspx; Programowanie perspektyny finansowej 2014-2020, 2014: 158.

The financial resources made available under cohesion policy during this period will be addressed to two categories of regions that were subject to separate rules of programming, but their identification has taken place in accordance with the principles of the framework Regulation. The first group consists of less developed regions which included 15 regions (voivodeships) at NUTS 2 level, as their GDP per capita does not exceed $75 \%$ of the average GDP for the EU. However, the status of the Mazowieckie region, now more developed, has changed; it has now left the category of less developed regions. This is due to the presence of the capital in the region - Warsaw with a significant growth potential, while smaller territorial units are characterised by a lower level of development similar to that of the poorest Polish regions. As a consequence, within this region there is very high internal differentiation, the highest among regions. The territorial dimension is reflected in the new cohesion policy, and, the connected regional policy implemented in Poland. The Partnership Agreement which sets out the strategy of activities undertaken under the cohesion policy, the common agricultural policy and the common fisheries policy in 20142020 indicates that interventions will be implemented corresponding to the existing potentials of individual territories and their needs. Areas of strategic intervention are 
pointed out, also supported by the Cohesion Policy funds, will include five Polish, lessfavoured regions of Eastern Poland, regional capitals with their functional areas, cities and city districts that require revitalisation due to the cumulative negative socio-economic phenomena, spatial and environmental issues, these are also rural areas insufficiently involved in the development processes and border areas as well as coastal (Programowanie perspektywy finansowej 2014-2020, 2014).

\section{Conclusion}

In summary, the achievement of the socio-economic model of the EU requires adherence to the principle of solidarity, of which cohesion policy is the practical dimension. But now this cohesion needs to be supported not only in the economic dimension, but also in the social one, to pursue the sustainable development path adopted by the EU. Thus, European cohesion policies should be built on both economic and social pillars. This could, in the long run, also be an important contribution to the creation of European solidarity. As we have argued in the paper there is no conflictual relationship between economic and social cohesion. The importance of social cohesion on the regional level and its contribution to the economic growth should be further discussed. The financial assistance granted under the cohesion policy supports the achievement of both dimensions of cohesion. It cannot be forgotten that the benefits from the implementation of this policy apply all MS, not just the beneficiaries of the aid.

Cohesion policy has evolved - from a purely redistributive policy to a policy supporting all regions, a determining factor in both its current and future importance in the EU. Currently, cohesion policy must be directed at fostering development to a greater extent, not only at equalizing differences.

In Poland, cohesion policy has led to a significant transformation in various spheres of socio-economic life. However, the focus should be on development-oriented activities, including projects related to the improvement of human and social capital, and in the sphere of education, which all play a fundamental role. In the current programming period, Poland needs to mobilise its own financial resources to support development projects as much as possible. When, in the next financial perspective, it will receive reduced funding from the EU, as it can be imagined, thanks to the improvement of its socio-economic 
situation, it will be necessary to continue the investments initiated thanks to EU funds to support the competitiveness of the economy.

External factors: globalisation (e.g. through changes in the pattern of production - value chain), the economic crisis and related macroeconomic constraints, demographic change, climate change, social exclusion, the challenges of environmental protection, energy problems, knowledge based economy and other externalities
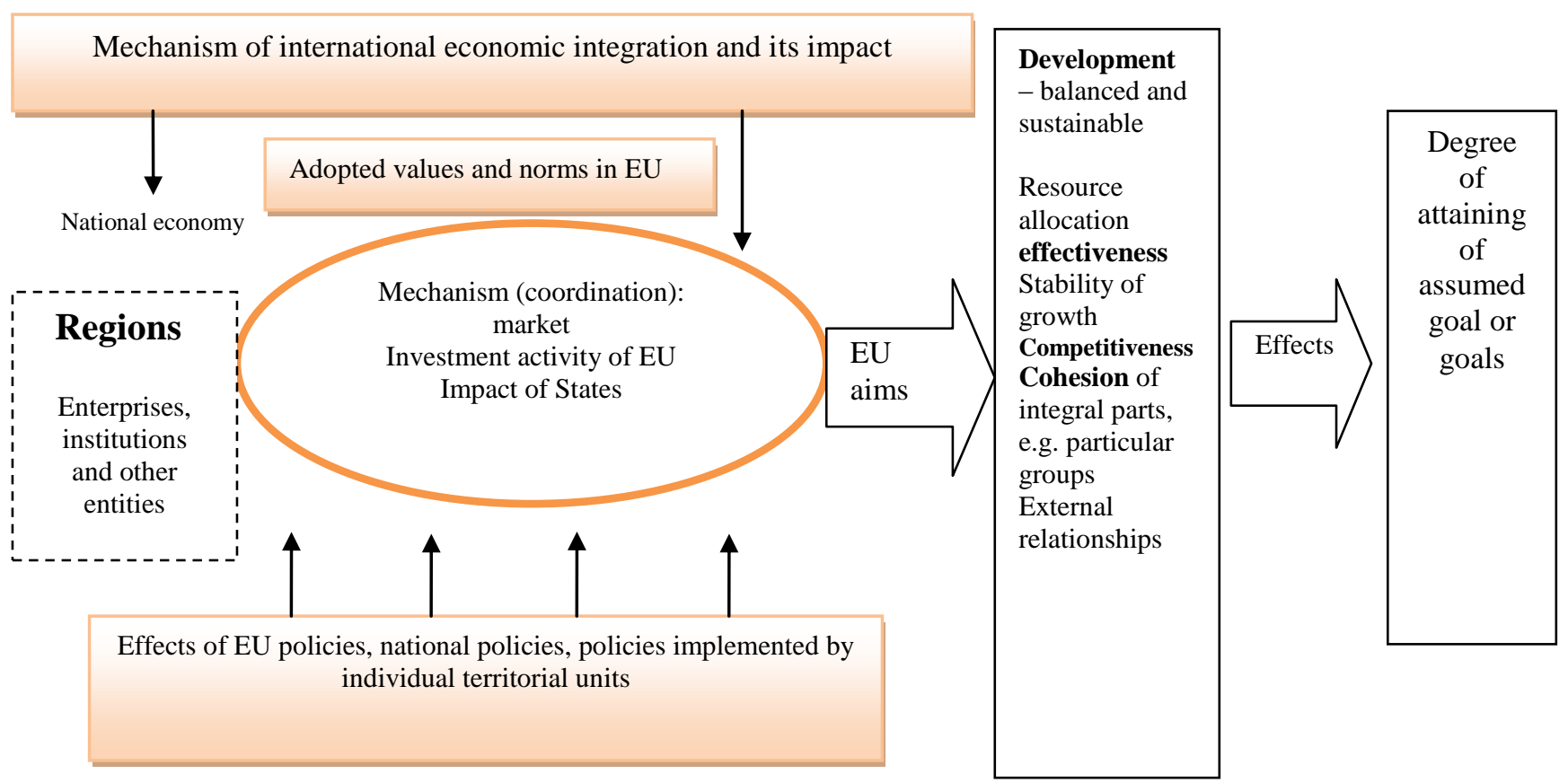

Figure 1. EU socio-economic model from the regional perspective - some assumptions

Source: Dziembała 2013: 166, figure 2.5 and some modifications with the use of: Ministry of Regional Development 2011: 12.

Table 1. Average values of variables for particular clusters: data for the period of 20032005

\begin{tabular}{|c|c|c|c|c|c|c|c|}
\hline $\begin{array}{c}\text { Cluster } \\
\text { No. }\end{array}$ & $\begin{array}{c}\text { Unemploy } \\
\text { ment rate } \\
(\%)\end{array}$ & $\begin{array}{c}\text { Economic activity } \\
\text { rate (\%) }\end{array}$ & $\begin{array}{c}\text { Average life } \\
\text { expectancy }\end{array}$ & Fertility rate & $\begin{array}{c}\text { HDI per capita } \\
\text { (in euro) }\end{array}$ & $\begin{array}{c}\text { Number } \\
\text { of cases }\end{array}$ & $\begin{array}{c}\text { Per cent } \\
(\%)\end{array}$ \\
\hline 1 & 9.30 & 62.37 & 72.02 & 1.332 & 2260 & 21 & 38.89 \\
\hline 2 & 7.21 & 69.25 & 75.57 & 1.190 & 5145 & 14 & 25.93 \\
\hline 3 & 19.25 & 64.53 & 74.76 & 1.249 & 3502 & 19 & 35.19 \\
\hline
\end{tabular}

Source: own calculations. 
Table 2. Average values of variables for particular clusters: data for the period of 20062008

\begin{tabular}{|c|c|c|c|c|c|c|c|}
\hline $\begin{array}{c}\text { Cluster } \\
\text { No. }\end{array}$ & $\begin{array}{c}\text { Unemplo } \\
\text { yment } \\
\text { rate } \\
(\%)\end{array}$ & $\begin{array}{c}\text { Economic } \\
\text { activity rate }(\%)\end{array}$ & $\begin{array}{c}\text { Average life } \\
\text { expectancy }\end{array}$ & Fertility rate & $\begin{array}{c}\text { HDI per capita } \\
\text { (in euro) }\end{array}$ & $\begin{array}{c}\text { Numbe } \\
\text { r of } \\
\text { cases }\end{array}$ & $\begin{array}{c}\text { Per } \\
\text { cent } \\
(\%)\end{array}$ \\
\hline 1 & 7.056 & 64.79 & 72.70 & 1.421 & 2952 & 16 & 29.63 \\
\hline 2 & 10.97 & 62.18 & 74.87 & 1.330 & 4654 & 21 & 38.89 \\
\hline 3 & 5.66 & 69.69 & 76.37 & 1.372 & 6755 & 17 & 31.48 \\
\hline
\end{tabular}

Source: own calculations.

Table 3. Average values of variables for particular clusters: data for the period of 20092011

\begin{tabular}{|c|c|c|c|c|c|c|c|}
\hline $\begin{array}{c}\text { Cluster } \\
\text { No. }\end{array}$ & $\begin{array}{c}\text { Unemploy } \\
\text { ment rate } \\
(\%)\end{array}$ & $\begin{array}{c}\text { Economic activity } \\
\text { rate (\%) }\end{array}$ & $\begin{array}{c}\text { Average life } \\
\text { expectancy }\end{array}$ & Fertility rate & $\begin{array}{c}\text { HDI per capita } \\
\text { (in euro) }\end{array}$ & $\begin{array}{c}\text { Number } \\
\text { of cases }\end{array}$ & $\begin{array}{c}\text { Per cent } \\
(\%)\end{array}$ \\
\hline 1 & 13.81 & 66.33 & 73.94 & 1.583 & 4258 & 11 & 20.37 \\
\hline 2 & 9.12 & 64.20 & 75.41 & 1.303 & 4573 & 31 & 57.41 \\
\hline 3 & 6.87 & 70.72 & 77.92 & 1.486 & 8256 & 12 & 22.22 \\
\hline
\end{tabular}

Source: own calculations.

Table 4. Clustering results of the regions of CEE countries by the k-mean method according to economic and social cohesion in the period of 2009-2011

\begin{tabular}{|l|r|r|r|r|r|r|r|}
\hline \multicolumn{1}{|c|}{ Regions } & $\begin{array}{r}\text { Result } \\
\text { classification }\end{array}$ & $\begin{array}{c}\text { Unemploy } \\
\text { ment rate } \\
(\%)\end{array}$ & $\begin{array}{c}\text { Economic } \\
\text { activity } \\
\text { ratio (\%) }\end{array}$ & $\begin{array}{c}\text { Average } \\
\text { life } \\
\text { expectancy }\end{array}$ & $\begin{array}{c}\text { Fertility } \\
\text { rate }\end{array}$ & $\begin{array}{c}\text { HDI } \\
\text { per } \\
\text { capita } \\
\text { (euro) }\end{array}$ & $\begin{array}{c}\text { Distance } \\
\text { from the } \\
\text { cluster's } \\
\text { centre }\end{array}$ \\
\hline BG33 - Severoiztochen & 1 & 13.43 & 66.20 & 73.40 & 1.63 & 2500.0 & 0.222 \\
\hline BG42 - Yuzhen tsentralen & 1 & 10.53 & 64.63 & 74.47 & 1.62 & 2533.3 & 0.328 \\
\hline LT00 - Lietuva & 1 & 15.67 & 70.40 & 73.30 & 1.52 & 6066.7 & 0.363 \\
\hline BG32 - Severen tsentralen & 1 & 10.90 & 62.73 & 73.40 & 1.51 & 2400.0 & 0.384 \\
\hline SK04 - Východné Slovensko & 1 & 17.70 & 66.30 & 75.33 & 1.65 & 6066.7 & 0.394 \\
\hline SK03 - Stredné Slovensko & 1 & 15.67 & 67.53 & 75.23 & 1.38 & 6866.7 & 0.467 \\
\hline BG34 - Yugoiztochen & 1 & 9.57 & 65.47 & 72.97 & 1.84 & 2733.3 & 0.517 \\
\hline BG31 - Severozapaden & 1 & 10.60 & 61.53 & 72.87 & 1.78 & 2200.0 & 0.530 \\
\hline EE00 - Eesti & 1 & 14.17 & 74.20 & 75.97 & 1.68 & 5666.7 & 0.566 \\
\hline LV00 - Latvija & 1 & 17.73 & 73.10 & 73.27 & 1.38 & 5200.0 & 0.576 \\
\hline HU31 - Észak-Magyarország & 1 & 15.97 & 57.53 & 73.17 & 1.43 & 4600.0 & 0.591 \\
\hline PL43 - Lubuskie & 2 & 9.87 & 63.03 & 75.77 & 1.36 & 4800.0 & 0.131 \\
\hline PL31 - Lubelskie & 2 & 9.93 & 65.73 & 76.07 & 1.36 & 4400.0 & 0.159 \\
\hline HU21 - Közép-Dunántúl & 2 & 9.57 & 63.93 & 74.57 & 1.23 & 5100.0 & 0.161 \\
\hline PL61 - Kujawsko-Pomorskie & 2 & 10.67 & 63.50 & 75.90 & 1.37 & 4833.3 & 0.163 \\
\hline PL51 - Dolnoslaskie & 2 & 10.67 & 64.50 & 76.07 & 1.27 & 5600.0 & 0.185 \\
\hline PL11 - Lódzkie & 8.73 & 67.03 & 74.67 & 1.33 & 5400.0 & 0.218 \\
\hline PL22 - Slaskie & 2 & 62.53 & 75.67 & 1.31 & 6233.3 & 0.222 \\
\hline
\end{tabular}




\begin{tabular}{|c|c|c|c|c|c|c|c|}
\hline PL62 - Warminsko-Mazurskie & 2 & 9.27 & 61.17 & 75.97 & 1.40 & 4500.0 & 0.232 \\
\hline HU22 - Nyugat-Dunántúl & 2 & 8.43 & 64.73 & 75.20 & 1.14 & 5233.3 & 0.244 \\
\hline PL34 - Podlaskie & 2 & 8.87 & 66.27 & 77.23 & 1.30 & 4500.0 & 0.255 \\
\hline HU10 - Közép-Magyarország & 2 & 8.13 & 65.90 & 76.23 & 1.18 & 5800.0 & 0.269 \\
\hline PL42 - Zachodniopomorskie & 2 & 11.53 & 61.17 & 76.00 & 1.30 & 5300.0 & 0.270 \\
\hline PL33 - Swietokrzyskie & 2 & 11.90 & 66.97 & 76.40 & 1.30 & 4666.7 & 0.282 \\
\hline PL41 - Wielkopolskie & 2 & 8.30 & 65.90 & 76.60 & 1.45 & 5666.7 & 0.300 \\
\hline RO31 - Sud - Muntenia & 2 & 8.60 & 65.07 & 73.70 & 1.33 & 2733.3 & 0.305 \\
\hline PL21 - Malopolskie & 2 & 8.77 & 65.53 & 77.70 & 1.38 & 4933.3 & 0.314 \\
\hline PL52 - Opolskie & 2 & 9.60 & 64.63 & 77.13 & 1.13 & 4766.7 & 0.328 \\
\hline HU33 - Dél-Alföld & 2 & 10.50 & 60.07 & 74.47 & 1.19 & 4666.7 & 0.330 \\
\hline PL63 - Pomorskie & 2 & 8.07 & 63.70 & 77.13 & 1.48 & 5266.7 & 0.340 \\
\hline PL32 - Podkarpackie & 2 & 11.37 & 65.10 & 77.80 & 1.31 & 4066.7 & 0.342 \\
\hline RO22 - Sud-Est & 2 & 8.43 & 61.27 & 73.63 & 1.28 & 2900.0 & 0.342 \\
\hline RO12 - Centru & 2 & 10.60 & 60.50 & 74.37 & 1.38 & 2866.7 & 0.352 \\
\hline RO41 - Sud-Vest Oltenia & 2 & 6.90 & 65.73 & 73.83 & 1.19 & 2866.7 & 0.362 \\
\hline RO32 - Bucuresti - Ilfov & 2 & 4.77 & 67.30 & 75.77 & 1.25 & 6033.3 & 0.403 \\
\hline RO42 - Vest & 2 & 5.90 & 62.03 & 73.50 & 1.20 & 3300.0 & 0.405 \\
\hline RO11 - Nord-Vest & 2 & 5.73 & 62.07 & 73.53 & 1.32 & 2833.3 & 0.406 \\
\hline HU23 - Dél-Dunántúl & 2 & 12.17 & 58.93 & 74.37 & 1.24 & 4766.7 & 0.410 \\
\hline SK02 - Západné Slovensko & 2 & 11.10 & 69.43 & 75.73 & 1.26 & 7200.0 & 0.458 \\
\hline RO21 - Nord-Est & 2 & 5.40 & 67.23 & 73.67 & 1.41 & 2466.7 & 0.473 \\
\hline BG41 - Yugozapaden & 2 & 6.13 & 72.07 & 74.90 & 1.41 & 3633.3 & 0.544 \\
\hline HU32 - Észak-Alföld & 2 & 14.37 & 57.27 & 74.17 & 1.35 & 4433.3 & 0.575 \\
\hline CZ06 - Jihovýchod & 3 & 7.07 & 69.83 & 78.47 & 1.47 & 7266.7 & 0.144 \\
\hline CZ05 - Severovýchod & 3 & 6.97 & 69.47 & 78.07 & 1.52 & 7100.0 & 0.158 \\
\hline CZ03 - Jihozápad & 3 & 5.37 & 71.00 & 77.87 & 1.47 & 7233.3 & 0.160 \\
\hline CZ02 - Strední Cechy & 3 & 4.90 & 71.33 & 77.60 & 1.56 & 8133.3 & 0.184 \\
\hline PL12 - Mazowieckie & 3 & 7.10 & 69.63 & 76.80 & 1.43 & 7200.0 & 0.211 \\
\hline SI01 - Vzhodna Slovenija (NUTS 2010) & 3 & 7.97 & 70.47 & 78.73 & 1.50 & 9833.3 & 0.220 \\
\hline CZ07 - Strední Morava & 3 & 7.97 & 68.83 & 77.57 & 1.42 & 6866.7 & 0.230 \\
\hline CZ08 - Moravskoslezsko & 3 & 9.73 & 68.50 & 76.37 & 1.46 & 6900.0 & 0.345 \\
\hline SK01 - Bratislavský kraj & 3 & 5.53 & 74.13 & 77.30 & 1.45 & 11000.0 & 0.393 \\
\hline CZ04 - Severozápad & 3 & 10.30 & 69.17 & 75.90 & 1.55 & 6766.7 & 0.405 \\
\hline CZ01 - Praha & 3 & 3.47 & 74.20 & 79.37 & 1.40 & 9800.0 & 0.421 \\
\hline SI02 - Zahodna Slovenija (NUTS 2010) & 3 & 6.10 & 72.03 & 81.03 & 1.62 & 10966.7 & 0.533 \\
\hline
\end{tabular}

Source: own calculation.

\footnotetext{
* Dr hab. Małgorzata Dziembała, professor at the University of Economics in Katowice.

I See: Pike, Rodríques-Pose, Tomaney 2006; Vanhove 1999: 252-291.

II Art. 3 (3), The Treaty on the Functioning of the European Union (consolidated version), The Official Journal of the EU, 2012/C 326/01.

III European Commission, 2014a: 179. In the previous programming periods, the amount of aid for the poorest regions was much smaller, because it accounted for $76 \%$ of the total aid going to the Structural
} 
Funds and the Cohesion Fund in 1989-1993. However, in the period 2014-2020 it is expected that helping the poorest regions will constitute nearly $73 \%$ of the total assistance which will be passed within the framework of cohesion policy. European Commission, 2014a: 186-187.

IV European Commission, 2014a: 180, 187.

$\mathrm{V}$ The definition of economic solidarity was developed on the basis of: Van Parijs: 2004: 375.

VI See discussion in: Dziembała 2013.

VII See also: Orłowski 2010b.

VIII Among them Malta and Cyprus regarded as single regions of NUTS2 level. Data obtained from Eurostat database (http://ec.europa.eu/eurostat/data/database, retrieved: 23.04.2015).

IX Data obtained from Eurostat database: (http://ec.europa.eu/eurostat/data/database, retrieved: 23.04.2015), analysis covered the period of 2003-2011 due to data availability.

$\mathrm{x}$ In this analysis, EU-10 includes all currently new MS, except for Croatia, Malta and Cyprus.

XI http://ec.europa.eu/regional policy/en/funding/available-budget/, retrieved: 14.04.2015.

XII Unless stated otherwise, the point 4 of the paper was prepared on the basis: Ministry of Infrastructure and Development, 2014.

XIII http://www.mir.gov.pl/fundusze/fundusze europejskie 2014 2020/strony/start.aspx, retrieved: 28.04.2015.

XIV http://www.mir.gov.pl/fundusze/fundusze europejskie 2014 2020/strony/start.aspx, retrieved: 28.04.2015.

\section{References}

- Agenda Terytorialna Unii Europejskiej. W kierunku bardziej konkurencyjnej i zrównoważonej Europy zróżnicowanych regionón (https://www.mir.gov.pl/rozwoj regionalny/Polityka przestrzenna/Spojnosc terytorialna/Documents/Age nda terytorialna UE 0710.pdf, retrieved 21.04.2015).

- Barro Robert J. and Sala-i-Martin Xavier, 1991, Convergence across States and Regions, "Brookings Papers on Economic Activity" (http://www.brookings.edu/ / media/Projects/BPEA/19911/1991a bpea barro salaimartin blanchard hall.PDF, retrieved 23.04.2015).

- Baun Michael and Marek Dan, 2014, Cobesion policy in the European Union, Palgrave Macmillan Publishers, London and New York.

- Benner Chris and Pastor Manuel, 2014, "Brother, Can you Spare some Time? Sustaining Prosperity and Social Inclusion in America's Metropolitan Regions", Urban Studies, LII(7): 1339-1356. DOI: 10.1177/0042098014549127.

- Camagni Roberto, Capello Roberta, 2015, "Rationale and Design of EU Cohesion Policies in a Period of Crisis", Regional Science Policy \& Practice, VII(1): 25-47. DOI: 10.111/rsp3.12047.

- $\quad$ Citizen's awareness and perceptions of EU regional policy, Report, Flash Eurobarometer 384.

- Dziembała Małgorzata, 2013, Spójność ekonomiczno-społeczna i konkurencyjność regionón w polityce Unii Europejskiej, Praca naukowa, Uniwersytet Ekonomiczny w Katowicach, Katowice.

- European Commission, 2014, Podsumowanie realizacji strategii „Europa 2020” na rzecz inteligentnego, trwałego wərostu gospodarczego sprzyjajacego właczeniu społecznemu, Komunikat Komisji, Komisja Europejska, Bruksela, 5.3.2014, COM (2014) 130 final.

- $\quad$ European Commission, 2014a, Inwestycje na rzecz. wzrostu gospodarczego $i$ zatrudnienia. Promowanie rozwoju $i$ dobrego rzadzenia w regionach UE $i$ miastach. Szósty raport na temat spójności gospodarczej, spotecznej i terytorialnej, Urząd Publikacji Unii Europejskiej, Luksemburg.

- European Commission, 2014b, Public opinion in the European Union, First results, Standard Eurobarometer 82.

- European Commission, 2010, Europa 2020. Strategia na rzecz. inteligentnego $i$ zrównoważonego roẓwoju sprayjajacego wtaczeniu społecznemu, Komunikat Komisji, Bruksela 3.3.2010, KOM (2010) 2020 wersja ostateczna.

- European Commission, 2010a, Zielona ksiega w sprawie spójności terytorialnej. Pržeksztatcenie różnorodności terytorialnej w site, COM (2008) 616 wersja ostateczna, Bruksela, dated of 06.10.2010. 
- $\quad$ Gorzelak Grzegorz, 2014, "Wykorzystanie środków Unii Europejskiej dla rozwoju kraju - wstępne analizy", Studia Regionalne i Lokalne, nr 3 (57): 5-25

- Green Paper on Territorial Cohesion, the way ahead, "Inforegio Panorama", No. 28, December 2008.

- Instytut Badań Strukturalnych [Institute for Structural Research], 2011, Ocena korayśsi uzyskiwanych przez państwa UE-15 w wyniku realizacji polityki spójności w krajach Grupy Wysz̨ehradzkiej, Raport końcowy, Warszawa. (https://www.ewaluacja.gov.pl/Dokumenty ewaluacyjne/Documents/Raport KorzysciUE 15zrealizacjiPS wV4 06022012x.pdf, retrieved 14.04.2015).

- Martin Ron., 2008, "National Growth versus Spatial Equality? A Cautionary Note on the New 'Tradeoff Thinking in Regional Policy Discourse", Regional Science \& Practice, I(1): 3-13. DOI: 10.1111/j.17577802.2008.00003.x.

- Mik Cezary, 2009, "Solidarność w prawie Unii Europejskiej. Podstawowe problemy teoretyczne", in C. Mik (ed), Solidarność jako zasada działania Unii Europejskiej, TNOiK, Toruń, 33-51.

- Ministerstwo Infrastruktury i Rozwoju [Ministry of Infrastructure and Development], 2014, Wplyw członkostwa Polski w Unii Europejskiej i realizowanej polityki spójności na rozwój kraju, Warszawa.

- Ministerstwo Rozwoju Regionalnego [Ministry of Regional Development], 2007, Polska, Narodowe Strategiczne Ramy Odniesienia 2007-2013 wspierajace warost gospodarczy i zatrudnienie.

- Ministry of Regional Development, 2011, How to strengthen the territorial dimension of the 'Europa 2020' and the EU cohesion policy. Background Report based on the Territorial Agenda 2020, Warsaw.

- Misiag Jan, Misiąg Wojciech and Tomalak Marcin, 2013, Ocena efektywności wykorzystania pomocy finansowej Unii Europejskiej jako instrumentu polityki spójności społeczno-gospodarczej orazpoprawy warunków życia, Wyższa Szkoła Informatyki i Zarządzania z siedzibą w Rzeszowie, Rzeszów.

- $\quad$ OECD 2011, Perspectives on Global Development 2012. Social Cohesion in a shifting world, OECD Publishing.

- Orłowski Witold Maria, 2010a, "Rozwój ekonomiczny Polsk i regionu Europy ŚrodkowoWschodniej", in A. Tucholska (ed), Europejskie wyzwania dla Polski i regionów, Ministerstwo Rozwoju Regionalnego, Warszawa.

- $\quad$ Orłowski Witold Maria, 2010b, W pogoni za straconym czasem, PWE, Warszawa.

- Pike Andy, Rodríques-Pose Andres and Tomaney John, 2006, Local and Regional Development, Routledge, London and New York.

- $\quad$ Programowanie perspektywy finansowej 2014-2020 - Umowa Partnerstwa, 23 May 2014.

- Prusek Andrzej, 2009, "Polityka spójności a efektywność społeczno-ekonomiczna", in A. Barteczek, A. Lorek, A. Rączaszek (eds), Polityka gospodarcza w Polsce i Unii Europejskiej na poczatku XXI wieku, UE w Katowicach, Katowice, 97-105.

- Rodrígues-Pose Andres and Tselios Vassilis, 2015, "Toward Inclusive Growth: is There Regional Convergence in Social Welfare?", International Regional Science Review, XXXVIII(1): 30-60. DOI: 10.1177/0160017613505201.

- Schiek Dagmar, 2013, Economic and Social Integration: the Challenge for EU Constitutional Law, Edward Elgar Publishing, Cheltenham.

- Swieboda Pawel, 2014, "Solidarity and cohesion", in Challenge Europe. Challenges and new beginnings: Priorities for the EU's new leadership, Issue 22, European Policy Centre, 42-46.

- The Treaty on the Functioning of the European Union (consolidated version), The Official Journal of the EU, 2012/C 326/01.

- Tondl Gabriele, 1995, Can EU's Cohesion Policy Achieve Convergence?, Research Institute for European Affairs, University of Economics and Business Administration Vienna, IEF Working Paper Nr. 9 (http://epub.wu.ac.at/1536/1/document.pdf, retrieved 22.04.2015).

- Van Parijs Philippe, 2004, "Cultural Diversity against Economic Solidarity", in P. Van Parijs (ed), Cultural Diversity versus Economic Solidarity, Proceedings of the Seventh Francqui Colloquium, Brussels 28 February - 5 March 2003, De Boeck \& Lareier s.a., Bruxelles, 371-396.

- Vanhove N., 1999, Regional policy: a European Approach, Ashgate Publishing Ltd, Aldershot.

- Vignon Jérôme, 2011, Solidarity and responsibility in the European Union, Policy Brief, No, 26 (http://www.institutdelors.eu/media/bref27 jvignon en.pdf?pdf $=_{\mathrm{Ok}}$, retrieved 14.04.2015). 
- Woźniak Michał Gabriel, 2012, "Spójność społeczno-ekonomiczna w kontekście tendencji do upowszechniania się kryzysu finansów publicznych w Unii Europejskiej”, in M.G. Woźniak (ed), Nierówności spoteczne a wrost gospodarçyy, Uniwersytet Rzeszowski, Rzeszów, Zeszyt 25, 5-29.

- Data obtained from Eurostat database: http://ec.europa.eu/eurostat/data/database, retrieved: 23.04.2015; analysis covered the period of 2003-2011 due to data availability.

- $\quad$ http://www.mir.gov.pl/fundusze/fundusze europejskie 2014 2020/strony/start.aspx, 28.04.2015.

- $\quad$ http://ec.europa.eu/regional policy/en/funding/available-budget/, 14.04.2015. 